\title{
Theoretical-practical articulation of the continuous learning of leadership in Nursing in light of Peter Senge
}

\author{
Articulação teórico-prática da constante aprendizagem da liderança na enfermagem à luz de Peter Senge \\ Articulación teórico-práctica de la constante aprendizaje del liderazgo en la enfermería a la luz de Peter Senge
}

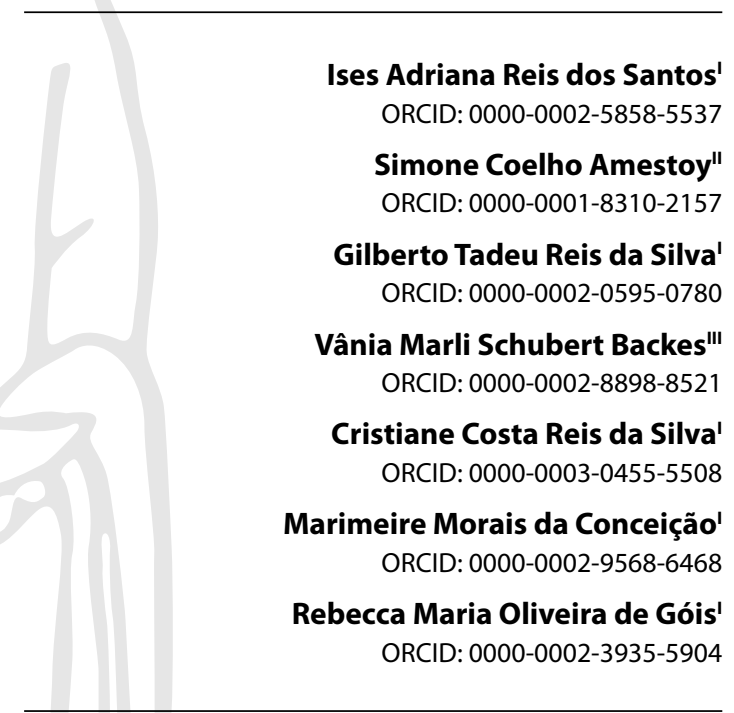

'Universidade Federal da Bahia. Salvador, Bahia, Brazil. "Universidade Federal do Vale de São Francisco. Petrolina, Pernambuco, Brazil.

"' Universidade Federal de Santa Catarina. Florianópolis, Santa Catarina, Brazil.

How to cite this article: Santos IAR, Amestoy SC, Silva GTR, Backes VMS, Silva CCR, Conceição MM, et al. Theoretical-practical articulation of the continuous learning of leadership in Nursing in light of Peter Senge. Rev Bras Enferm. 2021;74(4):e20201200. https://doi.org/10.1590/0034-7167-2020-1200

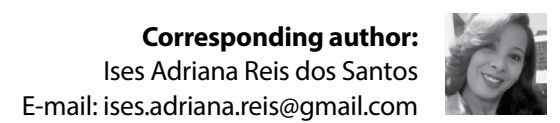

EDITOR IN CHIEF: Antonio José de Almeida Filho ASSOCIATE EDITOR: Fátima Helena Espírito Santo

Submission: $11-30-2020$

Approval: 02-05-2021

\begin{abstract}
Objective: To analyze the theoretical-practical articulation of the continuous learning of leadership in undergraduate Nursing. Methods: Case study carried out at a Northeast federal public university. For data collection, semi-structured interview techniques, workshops, and document analysis were applied. Forty Nursing students participated in the interviews, and 26 in the workshops. The data were submitted to Minayo's operative analysis using the Nvivo software. Peter Senge's concepts were adopted. Results: The students demonstrated a greater understanding of the theme throughout the course and recognized contributing elements to the continuous learning of leadership, such as behavioral characteristics and the use of methodological approaches integrated with theoretical and practical spaces. Final considerations: The teaching of leadership is relevant in Nursing education, and this has been recognized by students, but still requires changes for it to become operational, with an improvement and a theoretical-practical integration of the cultivated experiences, suitable to the reality of the craft.
\end{abstract}

Descriptors: Nursing; Leadership; Learning; Nursing Education; Nursing Professional Role.

\section{RESUMO}

Objetivo: Analisar a articulação teórico-prática da constante aprendizagem da liderança na graduação em Enfermagem. Métodos: Estudo de caso realizado em uma universidade pública federal do Nordeste. Para coleta, aplicaram-se as técnicas de entrevista semiestruturada, oficinas e análise documental. Participaram das entrevistas 40 discentes de enfermagem; e das oficinas, 26. Os dados foram submetidos à análise operativa de Minayo, com uso do software Nvivo. Adotaram-se os conceitos de Peter Senge. Resultados: Os discentes demonstraram maior entendimento da temática ao longo do curso e reconheceram elementos contributivos para a constante aprendizagem da liderança, como características comportamentais e uso de abordagens metodológicas integradas aos espaços teóricos e práticos. Considerações finais: O ensino da liderança mostra-se relevante na formação em Enfermagem, e isso vem sendo reconhecido pelos discentes, mas ainda necessita de mudanças para sua operacionalização, com aprimoramento e integração teórico-prática das vivências experimentadas, condizentes com a realidade dos cenários de atuação.

Descritores: Enfermagem; Liderança; Aprendizagem; Educação em Enfermagem; Papel do Profissional de Enfermagem.

\section{RESUMEN}

Objetivo: Analizar articulación teórico-práctica de la constante aprendizaje del liderazgo en grado en Enfermería. Métodos: Estudio de caso realizado en universidad pública federal del Nordeste. Para recogida, aplicaron las técnicas de entrevista semiestructurada, talleres y análisis documental. Participaron de las entrevistas 40 dicentes de enfermería; y de los talleres, 26. Los datos fueron sometidos al análisis operativo de Minayo, con uso del software Nvivo. Basados en Peter Senge. Resultados: Dicentes demostraron mayor entendimiento de la temática al largo del curso y reconocieron elementos contributivos a la constante aprendizaje del liderazgo, como características comportamentales y uso de abordajes metodológicas integradas a los espacios teóricos y prácticos. Consideraciones finales: La enseñanza del liderazgo se muestra relevante en la formación en Enfermería, y eso fue reconocido por los dicentes, pero aún necesita cambios para su operacionalización, con perfeccionamiento e integración teórico-práctica de las experiencias, condecentes con la realidad de los escenarios de actuación.

Descriptores: Enfermería; Liderazgo; Aprendizaje; Educación en Enfermería; Papel del Profesional de Enfermería. 


\section{INTRODUCTION}

The search for professional training and qualification represents a construct for the effective exercise of leadership by nurses. The need to develop and improve this competence across the board, at early stages of graduation, has been widely discussed, as it is identified as an element that contributes to the improvement of care offered to the population and of the interpersonal relationships established in the process of working in health care.

Certainly, frailties related to the precarious working conditions, usually experienced in health services, added to the low investment in training and qualification of nurse leaders, foster a scenario that makes it difficult to develop this competence. Thus, investments in actions aimed at improving leadership depend significantly on the support, recognition, and encouragement of health and education institutions ${ }^{(1)}$. Also, they occur due to the need to meet the implementation of a curriculum built on competences and skills, according to the requirements proposed by health services and National Curricular Guidelines for the Nursing Undergraduate Course $(D C N / E N F)^{(2)}$, regarding the formulation of the professional profile and, at the same time, in the improvement of teaching.

Consequently, this action can reverberate in improving the service and the quality of the offered health assistance. Thus, this measure aims to favor effective learning based on the four pillars of education: 1) learning to comprehend through a deconstruction of knowledge and reinvention of thought; 2) learning to do by acquiring work skills; 3 ) learning to live together and with others, which refers to the interpersonal relationships of participation and cooperation; and 4) learning to be, that is, the meaning of man in his integrality, complexity, and diversity ${ }^{(3)}$. Such concepts are in line with the theoretical precepts of Peter Senge's learning organization and continuous learning as a way of training and innovating ${ }^{(4)}$.

Thus, it is expected that the student, throughout the course, acquire the ability to deal with the complexities that surround the health scenario, with emphasis on the urgency of changes in pedagogical practices, including the contents inserted in the curricular components to encourage student autonomy. On this matter, studies seek to analyze the nurses' understanding about the teaching of leadership in undergraduate courses and about the tendencies to approach this theme; they also reveal the use of teaching-learning strategies for the development of this competence by nurses. However, weaknesses are still identified for the implementation of continuous leadership learning during the undergraduate course in Nursing, in view of only approaching and having knowledge of the topic at the end of the undergraduate course, more specifically, during the management curriculum component $t^{(5-6)}$.

In this sense, it is considered necessary to approach leadership in a transversal way, promoting it in several learning scenarios, since the beginning of graduation. Thus, in the present study, the knowledge in this respect is expanded based on the concepts of Peter Senge, through the "five disciplines of learning organizations", namely: 1) Personal mastery; 2) Mental models; 3) Shared vision; 4) Team learning; and 5) Systems thinking. Such disciplines concern theoretical-methodological actions that enable the development of learning skills(4).
In Nursing education, Senge's theoretical precepts can be adapted for the application of continuous leadership learning. This adjustment can be made with a view to changing the way of thinking and a greater possibility of innovations in the training scenario ${ }^{(4)}$. Therefore, it is based on the premise that the leadership posture does not equate to a position or role, but as a necessary competence for the development, adequacy, and improvement of the services offered to the population. Thus, the concepts of the aforementioned work favor understanding and reiterate the relevance of expanding knowledge on the theme as a stimulus for its development in educational institutions.

In addition, it is worth noting the low number of productions in Nursing addressing the continuous learning of leadership and/or that have used the theoretical framework mentioned. Therefore, the present study is guided by the following question: How does the theoretical-practical articulation take place for the continuous learning of leadership in undergraduate Nursing?

\section{OBJECTIVE}

To analyze the theoretical-practical articulation of the continuous learning of leadership in undergraduate Nursing.

\section{METHODS}

\section{Ethical aspects}

We complied to the recommendations of Resolutions 466/12, $510 / 16$, and $580 / 18$ of the National Health Council. The project was submitted to and approved by the Research Ethics Committee; and, after approaching the students, they were invited to participate in the research. All collaborators read and signed the Free and Informed Consent Term in two copies (participant and researcher), as well as being informed about their right to accept or not participate in the research or to withdraw at any time without prejudice.

\section{Theoretical methodological framework}

For this study, the theoretical precepts of Peter Senge's work "The fifth discipline: the art and practice of the learning organization"(4) were adopted, aiming to present a new look at the training of nurse-leaders.

The author is considered one of the world's influential thinkers in management and leadership; founder and director of the Society for Organizational Learning (SOL) and author of the learning organization concept. Graduated in Engineering from Stanford University, he also has a degree in Philosophy, a Master's in Social Systems Models, and a PhD in Administration from the Massachusetts Institute of Technology (MIT) $)^{(4)}$.

For a better understanding of the concepts apprehended by the author, we sought to adapt the five disciplines to Nursing, in order to promote reflections, dialogues, changes in behavior, criticism, and autonomy of future Nursing professionals about the development of leadership during the undergraduate course. It is believed that this preparation allows the insertion of graduates holding this differential in the job market, along with technical and scientific knowledge. 
Therefore, the five disciplines refer to a deep reflection on the use of theoretical and methodological approaches for the development of central learning capacities (Figure 1), based on the principle of changing the model of education based on unilateralism, in which only the teacher is the holder of knowledge (it is said of the banking education model) and power relations. These relationships are present in several contexts: for example, in direct actions of the boss towards subordinates to achieve goals, in the imposition of submissive postures, or in the teacher-student relationship based on correct answers, in the mandatory use of uniforms, in the predictable and controlled, in the competitiveness, distrust, and fragmentation of the whole.

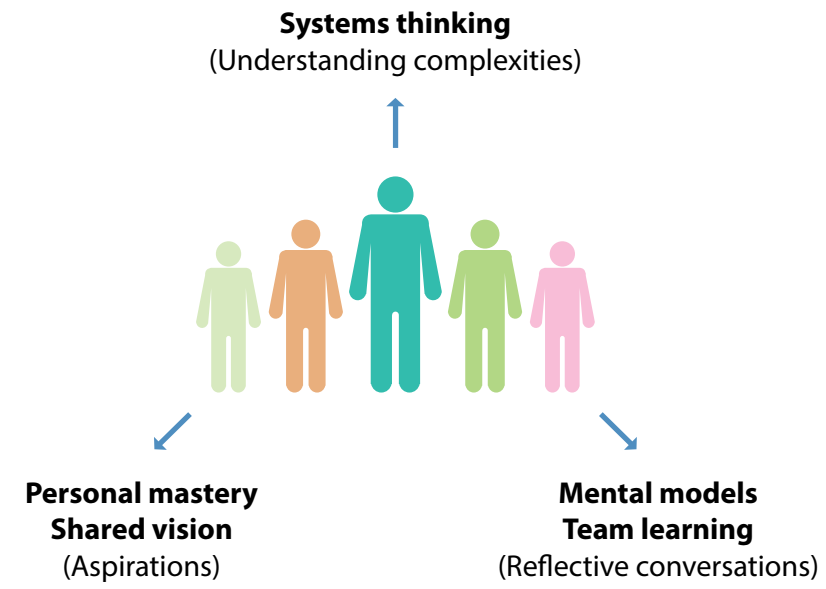

Source: Adapted from Peter M. Senge, 2018.

Figure 1 - Central group learning skills

Thus, the five disciplines complement each other and, therefore, must be applied together, so that one can relate to the other and vice versa (Figure 2).

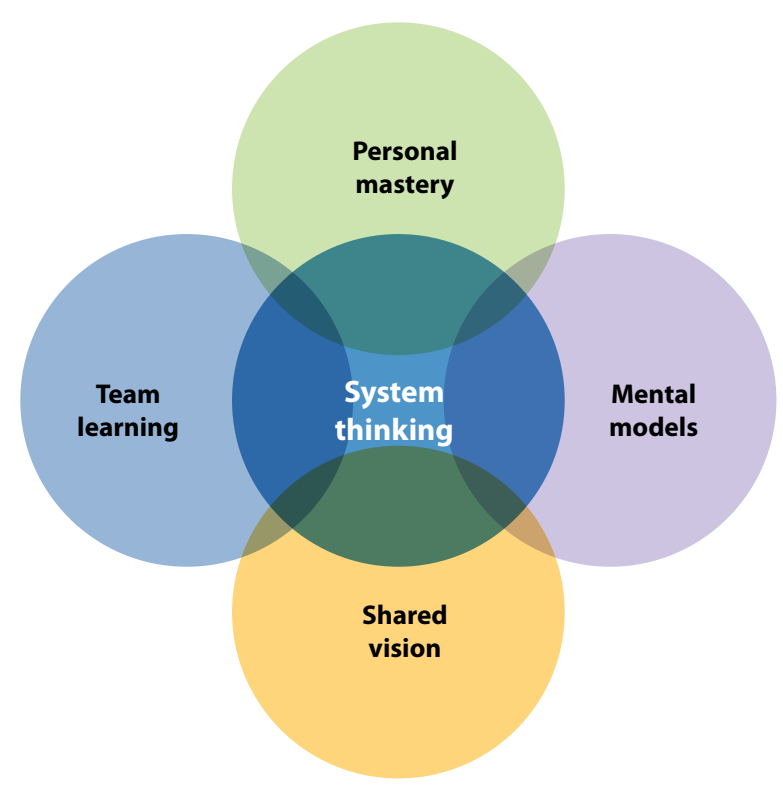

Source: Adapted from Peter M. Senge, 2018.

Figure $\mathbf{2}$ - The five disciplines and their interrelationships
Aspirations, with the Personal Mastery discipline, encompass individual attributes and competences, as individuals are considered capable of obtaining better results when the continuous interest in learning is stimulated. Similarly, there is the Shared Vision discipline, based on the concepts and personal discernment of sharing ideas with the purpose of reaching common goals and promoting participation from everybody ${ }^{(4)}$.

The discipline called Mental models is more related to reflective conversations and dialogues concepts, concepts contribute to advances in the organization. However, these could forgo implementation due to the influence of preconceived ideas or due to negative reflexes of thinking and acting ${ }^{(4)}$. In this regard, the Team learning discipline results from actions thought and applied through Personal mastery along with Shared vision, arranged in the dimension of shared reflection on complex subjects ${ }^{(4)}$. They also portray the complementary performance of the group members (with confidence, innovation, coordination) and their participation in other teams. These interactions seek to promote, encourage, and disseminate practices, developing everybody's skills.

Finally, Systems thinking, or the fifth discipline, is considered a managerial and leadership tool; it is the central element and cuts through all other disciplines, based on which it is possible to understand the complexity of situations ${ }^{(4)}$. In this sense, the application of such discipline helps to clarify paradigms by involving changes in thoughts and the need to know the whole (its globality) in order to understand the parts.

\section{Study type}

Case study with a qualitative approach, linked to the matrix project entitled "Teaching leadership in undergraduate Nursing: teachers' and students' perspectives". To structure this study, the Consolidated Criteria for Reporting Qualitative Research (COREQ) instrument was used ${ }^{(7)}$.

\section{Methodological procedures}

\section{Study scenario}

The study was carried out at a federal public university in the Northeast of Brazil.

\section{Data source}

Sixty-six students participated in the study, aged over 18 years, and regularly enrolled in the Nursing course in the $1^{\text {st }}$ to $10^{\text {th }}$ semester.

Of the total, 40 were individually interviewed. For the workshops, students who attended the curriculum component of Health Systems and Services Management were invited, and in the first workshop, the class consisted of 15 students and, in the second, 11 students. These groups took the course in different semesters.

For the research, a documentary analysis was also carried out covering the pedagogical project of the course and the plans of the curricular components, provided by the coordination of the higher education institution ( $\mathrm{HEI})$. Students transferred from other schools were excluded from both stages. 


\section{Data collection and organization}

First, a sociodemographic questionnaire was applied; then, the interviews with open questions were conducted individually, in a private space, on dates and times previously agreed with the interviewees, in the period between November 2017 and July 2018.

In the first stage of the research, the interviewees were selected according to the snowball sampling technique, which uses chains of references ${ }^{(8)}$. The definition of the number of participants followed the saturation criteria, that is, the interviews were ceased when there were no more contacts made and/or the data were repeated. The interviews followed guiding questions inserted in a research instrument designed for this purpose. The anonymity of the participants was preserved, identified by the letter $\mathrm{S}$ (student) plus a number corresponding to the order in which the interviews were carried out (S1, S2 ... S40).

To validate the information collected, two workshops were held, called W1 and W2. The workshop consists of a dialogical space for the establishment of the authentic communication process, which makes it possible for everyone to participate without a judgment of the ideas conceived ${ }^{(9-10)}$. The fragments extracted from the workshops were identified by the respective acronyms, W1 and W2, followed by the letter S (referring to the student) and number corresponding to the order of participation (e.g., W1S1, W2S1).

These workshops were scheduled in advance and took place in the months of July and December 2017 with an approximate duration of 30 to 45 minutes. Four researchers (undergraduate and graduate students and teachers) previously trained for the actions were present.

In the third and final stage of collection, documents provided by the coordination of the undergraduate course were repeatedly read. The documentary research included the following research objects: the approved and implemented syllabus in the second semester of 2017, the pedagogical project for the undergraduate Nursing course in 2010 (PPC2010) and the teaching projects of the curricular components (CC1 to CC10) specific to the area for the period between 2010 and 2012, all of which are in the process of being updated.

\section{Data analyses}

Minayo's operative proposal was used to analyze the findings ${ }^{(11)}$, associated with the triangulation technique of the collected data ${ }^{(12)}$.

Thus, the following phases were covered: 1) ordering, with the organization of the collected materials, reading/rereading, and arranging the transcriptions; 2) categorization by searching for units of meaning, pre-analysis based on empirical and theoretical material, separated by subjects in Word, for the classification and gathering of information; 3 ) attentive, in-depth, and pervasive reading of categories and units of meaning; 4 ) conclusion, with the presenting of the information ${ }^{(11)}$. The data were processed using the NVIVO 11 software, in which the materials were classified by similarities and correspondences to the objectives of the work.

This process highlighted factors that contribute to the continuous teaching of leadership in undergraduate Nursing, brought together in this study in two categories: Continuous learning of leadership in undergraduate Nursing: articulation between theory and practice; and Intervening factors and possibilities of continuous learning of leadership during undergraduate Nursing.

\section{RESULTS}

\section{Continuous learning of leadership in undergraduate Nurs- ing: articulation between theory and practice}

In this category, the students declared in their testimonies that the training model proposed by the HEl encourages the continuous learning of leadership during the graduation course, since, like Peter Senge's precepts, they enable the promotion of aspirations, the expansion of dialogue (of reflections), and understanding of complex situations. However, weaknesses were found in the teaching of the competence in the analyzed documents, although the subject is implicit in the pedagogical project of the course and in its curricular components:

[...] to balance theory and practice as a mean to build an entire competency. The need to provide answers to problems posed by the practice instigates students and teachers to seek knowledge. The appropriation of reality only occurs fully through practical experiences. Learning starts from doing, as to enable knowing how to do something, and having the ability to do it over again [...]. (PPC2010)

[...] instruct the student technically, critically, and scientifically for the process of caring [...] provide instruments and skills essential to the performance of SAE [...] critically analyze the effectiveness of systematized care and the repercussion of the nursing process. (CC5)

Develop and apply technical-scientific and managerial knowledge with ethical skills and attitudes in decision-making in the care process [...] to expand, integrate, and consolidate knowledge and skills related to care. Develop the capacity for critical reflection on reality, to seek alternative solutions to problems and new knowledge. (CC9 e CC10)

The forming of the leader can occur in a continuous manner throughout the Nursing undergraduate course, associating theory and practice, and in conjunction with the curriculum components. When this happens, student involvement to work as a team is encouraged, as well as their willingness to assume a relational behavior favorable to the adoption of a leadership posture during care management, which translates into integration among members through dialogue (reflections) and encouraging the understanding of the complexities proposed by Senge. This stimulus was highlighted in some of the speeches:

[...] taking the whole theoretical framework, the image of the nurse leader as a manager is stimulated by the teachers, so that we exercise this in practice, especially in this semester, which is the curricular internship, so that, when we are future professionals, we already know how to deal with the situations. (S35)

[...] the teacher encourages the students, in the group itself, to establish leadership, this already makes the student prepare to be acting as one in the future. (S21) 
However, the students who participated in the workshops mentioned the urgency of inserting this theme since the beginning of the course, in a transversal way, aligned with the component of Health systems and services management. This thinking is consistent with the concept of Senge in the application of Team Learning in order to develop the Shared Vision and Personal mastery. Inserting the teaching of this competence throughout the theoretical-practical activities was pointed out as a strategy to make better use of the different training scenarios in pursuit of this purpose, including in realistic simulation laboratories and in services and/or communities.

And who knows, in the future, talking and articulating with other disciplines, we can give a "heads up" to the coordinators of the disciplines about what the students demand, because it is also a way of contributing to our education. (W1S7)

[...] It would be good to talk to management so this could be something that is mandatory, because, since the nurse is a born manager and the manager is a coordinator, he is still a leader, it is important that everyone goes through this, understands this leadership process, knows how we will be dealing with it. (W1S8)

\section{Intervening factors and possibilities of continuous learning of leadership during undergraduate Nursing}

Another aspect addressed, in some statements, expressed criticism in relation to the stagnant Nursing curriculum, which prioritizes technical actions and procedures as intervening factors in the continuous learning of leadership in undergraduate courses, which reverberates beyond training:

[...] the difficulties are [sic] exactly the sense of comfort, the stagnant curriculum, extremely technical, biomedical, centered on the disease. (S10)

[...] fragility [...] not having it since the beginning of graduation [teaching of leadership], there is no focus related to that. (S11)

It is very difficult, a lot of responsibility. I have never seen the teaching of leadership done by the teachers. Since I joined here, I have never seen the teaching of leadership, even in theories. (S36)

[...] because here we see many events talking about care, gender issues, violence, and we don't have any kind of seminar that addresses this topic, that talks about these issues of leadership, nurses and leadership, things of the sort. (W1S7)

Certainly, despite the criticisms reported, changes in the pedagogical project of the course may give rise to new possibilities for teaching to advance in the training of nurse-leaders:

[...] approximation with an integrated curriculum model. [...] the felt need to reduce the fragmentation existing in the disciplinary curriculum and in preparing the student to deal with the complexity of the situations in health; [...] it will contribute to the students' motivation, resulting in their active participation, both in the teaching-learning process and in the spaces where the university and society operate. [...] organized by units, which are articulated around intervention axes in health reality, concepts, and actions that ensure the development of the skills expected for the professional nurse. (PPC2010 - Course profile)

[...] instrumentalize, technically, critically, and scientifically, the student for the care process [...] to provide instruments and skills essential to the performance of SAE [...] critically analyze the effectiveness of systematized care and the repercussion of the nursing process. (CC5)

The students suggested, both in the interviews and in the workshops, the application (in the field of practice) of new methodological approaches, teaching strategies, knowledge, and/or productive experiences. These suggestions corroborate Senge's understanding of the incentive to expand dialogical reflections and promote aspirations, by articulating the theme with other curricular components:

[...] to access content, videos that bring this leadership theme, how to be a good leader, how to position yourself ethically, professionally, in order to facilitate group relationships, because leadership is expressed by someone to a group, from someone to a system, for a service, thus, what is extremely facilitating of this process of leading is good interpersonal relationships. (S24)

[...] a pilot project and could be articulated with the disciplines [...] in which there is hospital practice, workshops, forums, promote events that speak more about leadership. (W1S7)

[...] we can set goals and plan how we can improve tomorrow. [...] to change that process if it is not good or to take something that is good and multiply it, to overcome the bad things. (W2S1)

Considering that productive experiences can really make a big difference when making decisions; for example, I believe that in college we take as a basis the experiences that teachers pass on to us. Every time a teacher tells us about his experience in the field, we end up, willingly or unwillingly, absorbing some of that experience. These experiences end up helping us a lot when making decisions and making choices. (W2S10)

\section{DISCUSSION}

The results, in the students' perception, signaled an encouragement towards continuous learning of leadership in undergraduate Nursing, both in theoretical and practical spaces. However, it is assumed that this information may have been unexplored during the training process and/or are only implied in the analyzed documents, which present as a proposal the training of competent and qualified professionals for the performance of care management, which can be understood as a limited and mechanistic view of the profession.

Thus, the knowledge and understanding of the "Leadership" competence are necessary, since they permeate all scenarios where the characteristics attributed to the leader, over time, have undergone transformations and are variably related to the complex situations that can be encountered. Therefore, it is clear that the pedagogical plan presents the parts as fragments of teaching and fails to see that they all work together in a systemic thought.

Furthermore, the adoption of this learning leads to the understanding of the individual as "being" and to his relationship 
with the world in search of his development, the expansion of the capacity to constantly create himself, through a behavior change, within the systemic perspective as considered by Senge ${ }^{(4)}$. In other words, this results in a new understanding of being a student and comprehending the meaning of the profession of Nursing and human beings, given the complexity of their work process.

In addition, the students who participated in the interviews and workshops pointed out that the construction of the leader can occur in the course of graduation, in a transversal manner, with the other curricular components. Such perceptions coincide with Senge's theory when it comes to using the thought of personal mastery as an instrument of personal growth and learning, based on the ability to focus on intrinsic interests, to the detriment of secondary goals ${ }^{(4)}$.

Although criticisms of the curriculum emerged in the reports and were identified as weaknesses in the training of nurse-leaders, possibilities and strategies that facilitate the stimulation of the development of this competence were also evidenced.

In this sense, learning, according to Senge's perspective, expresses the origin of leadership defined as a process of learning, seeking to expand the individual and collective capacities of students in the construction of the results that they really want to produce ${ }^{(4)}$. The same is observed in an international study on the development of leadership in undergraduate and graduate courses, which recognizes clinical and academic spaces as scenarios to encourage the association between Nursing theory and practice, as they favor learning through action. Furthermore, the teaching of leadership encourages critical action during the improvement of competences and skills, such as decision making, resilience, and confidence through a workforce with a high level of emotional intelligence ${ }^{(13)}$.

It is noticed, therefore, that the construction of the leader during graduation takes place in an articulated way between technical-scientific knowledge, theory, and practice in the learning services, as well as in the simulation laboratories. This approach aims to prepare future professionals capable of assuming behaviors, skills, and attitudes consistent with the moral, cultural, and economic principles required by society ${ }^{(5)}$, in view of the various external influences suffered during the execution of their work.

A study reports that, in Nursing, the nurse's leadership style allows to clearly analyze a situation that is presented and effectively and efficiently act towards making decisions and resolve actions $^{(14)}$. However, one of the weaknesses in the teaching of such competence stems from a late exposure of the student to this theme (Leadership). In the researched institution, this experience is only available in the $8^{\text {th }}$ semester, when the students are already nearing course conclusion.

Thus, it is considered essential to insert leadership teaching since the first semester, in an effort to effectively develop it early, valuing the maturity of the undergraduates to understand and improve it during the course. Likewise, preparing and motivating teachers for this purpose can be a collaborative strategy to bring about such a change.

Another relevant result was the conception of students in regard to the curriculum, as they identified the emphasis on technical activities and procedures as intervening factors in the continuous learning of leadership in undergraduate courses, which raised criticism and evidenced the need for flexibility and a greater connection between theory and practice, as well as between teaching and service. Research on Nursing challenges and solutions in Sub-Saharan Africa highlighted leadership as a driver of change for undergraduate students. However, they experienced a lack of investments and incentives for the development of skills in training institutions, which maintained unresponsive curricula, shortage of teachers, as well as teaching and learning resources ${ }^{(15)}$. Such results reiterate the upkeep of weaknesses in the training of nurse-leaders, as well as the stagnant state of the Nursing curriculum, as evidenced in this study.

In view of these aspects, and with the perspective of fostering continuous learning, promising and lasting results can be seen through the use of Systems Thinking by the theoretician Peter Senge in small and specific actions ${ }^{(4)}$. It is known that the use of this discipline in continuous learning produces autonomous, active, and effective professionals, attuned to the processes, which favors the minimization of errors, improves decision-making, and resolvability of actions, in addition to contributing to the offered assistance ${ }^{(14)}$.

Thus, it is considered essential to invest in the training of nurseleaders through the application of methodological resources that provide effective and continuous learning of leadership even during graduation. In this sense, changes in the pedagogical project of the course may provide elements that are consistent with Systems thinking ${ }^{(4)}$ and generate possibilities to advance in the training of nurse-leaders, in order to value the multiplicity of learning spaces, with the integration of components and overcoming content fragmentation.

In addition, the students mentioned the relevance of the approach and insertion of new methodological solutions, strategies, knowledge, and/or productive experiences. In practice, this includes the articulation of the pedagogical project with other curricular components during the course of graduation, holding workshops, forums, discussions on the theme of leadership, activities in the field of practice, and/or simulation laboratory, which adds substantial benefits to the development of that competence.

Such benefits become even more important in view of the complexity of the services and the significant lack of teaching of leadership throughout the Nursing training process. Thus, the participation of nurse-leaders as facilitators of the teachinglearning process and the establishment of partnerships between the educational institution and health services is essential, with the use of methodological resources, spaces that encourage autonomy, decision-making, and communication. These are fundamental elements that contribute to the continuous learning of leadership during graduation and throughout the profession, as the literature points out ${ }^{(16-19)}$.

The new methodological approaches integrated with the fields of practice represent essential tools and spaces for the early development of skills and abilities by undergraduate Nursing students, as they provide reflections on the exercise of leadership. It is noted that Nursing education has ways of stimulating the continuous learning of leadership by using means that make it possible for students to approach theory and practice scenarios, as well as to experience this competence in everyday situations.

A study on the pedagogy of innovative teaching in Nursing education points to the importance of selecting more effective 
strategies to be worked with the teacher in order to stimulate the development of leadership ${ }^{(20)}$. Another research highlighted the importance of using methodological resources and active methodologies for the development of this competence in Nursing, as it encourages student commitment and autonomy, in addition to favoring decision making and building healthy interpersonal relationships ${ }^{(5)}$. Such results converge to others, who envisioned possibilities for transformation and improvement of health care through the development of leadership in Nursing, through the construction and improvement of personal capacities to understand and influence other people in the learning environments ${ }^{(21-22)}$, as well as making the assistance provided more qualified and efficient ${ }^{(23-24)}$.

Therefore, the promotion of metanoia becomes essential, a term that, according to Senge, means a change in mentality/behavior and that requires the commitment of all individuals involved in this construction ${ }^{(4)}$. In addition to systems thinking, the other disciplines proposed by the author that encompass Personal mastery, Mental Models, Shared vision, and Team learning can be improved by the Nursing student with the support of teachers and the educational institution. However, the training of nurseleaders requires collective engagement, and the pillars defined in the pedagogical project of the course guide the pedagogical practices of teachers and the active participation of students in the construction of this leadership potential.

\section{Study limitations}

As for the study limitations, it is noteworthy that it was developed only with students in a single locus of research, and it is pertinent to include, in future research, a greater number of participants and other institutions of higher education, both public and private, in order to expand understanding about the different nuances that permeate the object of investigation.

\section{Contributions to the field of Nursing}

The research contributes to the construction of knowledge related to the exercise of leadership in nurses and uses a theoretical framework relevant to the development of teaching this competence. The need to strengthen educational practices throughout Nursing undergraduate courses was evidenced, with the use of active methodologies and experiences that enhance the development of leadership.

\section{FINAL CONSIDERATIONS}

The study sought to analyze the theoretical-practical articulation of continuous leadership learning during undergraduate Nursing course. In the documentary research, it was identified that the curriculum, even in an implicit way, proposes strategies that, when used properly, enable the training of professionals with leadership profiles. In addition, the students, both in the interviews and in the workshops, recognized the incentive for the development of this competence and the need to train leaders during graduation who are able to deal with the complexities present in the work scenarios.

In this sense, Peter Senge's theoretical framework makes it possible to seed new possibilities of looking at the teaching of leadership in Nursing and its interfaces, in the understanding of Systems thinking, making it possible to visualize the subject as a whole in order to understand the parts. In a proposal for transformation, in addition to breaking paradigms, it is possible to foster changes in the pedagogical project of the course of the researched institution, as well as other HEls in the country, with a view on covering the training of nurse-leaders.

When observing that the curriculum exposes some limitations of teaching, as pointed out by the students, with emphasis on technical actions and procedures, which increases the unpreparedness and insecurity of these future professionals for performing a leadership role and further distances them from the purpose to work this competence across the board during graduation. On the other hand, the use of innovations and the diversity of methodological approaches integrated into theoretical and practical spaces contributes to the teaching of leadership. Therefore, it is necessary to improve the quality of these experiences during the learning process, in order to stimulate the development of professional skills and abilities in supportive environments that actually portray reality and associate theory and practice, with direct benefits in the quality of care.

Leadership can and should be developed continuously, but this does not depend only on technical knowledge, as it includes other variables such as professional experience itself, in addition to self-knowledge, identification of weaknesses, and opportunities to better exercise it in the work process in health services.

The present study is of great relevance for the construction of knowledge related to the exercise of Nursing leadership, and it demonstrates the need to strengthen educational practices throughout the teaching-learning process, from the first semesters, in Nursing undergraduate courses, with the use of active methodologies and experiences related to leadership development.

It concludes with the understanding that it is also essential to cultivate this knowledge in a transversal way to other curricular components since the beginning of the course.

\section{FUNDING}

Programa de Apoio a Jovens Doutores da Universidade Federal da Bahia (PROPESQ) [Support Program for Young Doctors from the Federal University of Bahia] — financing of the parent project; and Coordenação de Aperfeiçoamento de Pessoal de Nível Superior (CAPES) [Coordination for the Improvement of Higher Education Personnel] — financial support related to the master's scholarship.

\section{REFERENCES}

1. Wardani E, Ryan T. Barriers to Nurse Leadership in an Indonesian Hospital Setting. J Nurs Manag. 2019;27(3):671-8. https://doi.org/10.1111/ jonm.12728 
2. Ministério da Saúde (BR). Parecer Técnico n 28/2018. Recomendações do Conselho Nacional de Saúde (CNS) à proposta de Diretrizes Curriculares Nacionais (DCN) para o curso de graduação Bacharelado em Enfermagem. Ministério da Saúde [Internet]. 2018[cited 2020 Nov 26]. Available from: https://conselho.saude.gov.br/resolucoes/2018/Reso573.pdf

3. Delors J. Educação: um tesouro a descobrir. 7a ed. São Paulo: Cortez, 2018. 240 p.

4. Senge PM. A quinta disciplina da organização que aprende; tradução: Gabriel Zide Neto, OP Traduções - 35a ed. Rio de Janeiro: BestSeller, 2018. $640 \mathrm{p}$.

5. Caveião C, Peres AM, Zagonel IPS, Amestoy SC, Meier MJ. Teaching-learning tendencies and strategies used in the leadership development of nurses. Rev Bras Enferm. 2018;71(Suppl 4):1531-9. https://doi.org/10.1590/0034-7167-2017-0455

6. Amestoy SC, Trindade LL, Silva GTR, Santos BP, Reis VRSS, Ferreira VB. Leadership in nursing: from teaching to practice in a hospital environment. Esc Anna Nery. 2017; 21(4):e20160276. https://doi.org/10.1590/2177-9465-ean-2016-0276

7. Tong A, Sainsbury P, Craig J. Consolidated criteria for reporting qualitative research (COREQ):a 32 -item checklist for interviews and focus groups. Int J Qual Health Care. 2007;19(6):349-57. https://doi.org/10.1093/intqhc/mzm042

8. Kaplan CD, Korf D, Sterk C. Temporal and social contexts of heroin-using populations: an illustration of the snowball sampling technique. J Nerv Ment Dis. 1987;175(9):566-74. https://doi.org/10.1097/00005053-198709000-00009

9. Amestoy SC, Oliveira AFL, Thofehrn MB, Trindade LL, Santos BP, Bao ACP. Contributions of Paulo Freire to understanding the dialogic leadership exercise of nurses in the hospital setting. Rev Gaúcha Enferm. 2017;38(1):e64764. https://doi. org/10.1590/1983-1447.2017.01.64764

10. Lima MM, Reibnitz KS, Kloh D, Vendruscolo C, Corrêa AB. Dialogue: network that intertwines the pedagogical relationship into the practicalreflective teaching. Rev Bras Enferm. 2016;69(4):654-61. https://doi.org/10.1590/0034-7167.2016690406i

11. Minayo MCS, Costa AP. Técnicas que fazem uso da palavra, do olhar e da empatia. Pesquisa qualitativa em ação. Aveiro, Portugal: Ludomedia; 2019.63 p.

12. Garnelo L. Avaliação por triangulação de métodos: abordagem de programas sociais. Cad Saúde Pública. 2006;22(5):1115-17. https://doi. org/10.1590/S0102-311X2006000500025

13. James AH. Action learning can support leadership development for undergraduate and postgraduate nurses. Br J Nurs. 2018;27(15):876-80. https://doi.org/10.12968/bjon.2018.27.15.876

14. Phillips JM, Stalter AM, Dolansky MA, Lopez GM. Fostering future leadership in quality and safety in health care through systems thinking. J Prof Nurs. 2016;32(1):15-24. https://doi.org/10.1016/j.profnurs.2015.06.003

15. Bvumbwe T, Mtshali N. Nursing education challenges and solutions in Sub Saharan Africa: an integrative review. BMC Nurs. 2018;17:(3). https://doi.org/10.1186/s12912-018-0272-4

16. Martins BG, Silva LMC, Capaccioli BRBS, Neves VR, Balsanelli AP. Development and validation of a leadership training program for nurses. Texto Contexto Enferm. 2019;28:e20180048. https://doi.org/10.1590/1980-265x-tce-2018-0048

17. Miles JM, Scott ES. A New Leadership Development Model for Nursing Education. J Prof Nurs. 2019;35(1):5-11. https://doi.org/10.1016/j. profnurs.2018.09.009

18. Caveião C, Nascimento PA, Visentin A. Formação da liderança em enfermagem: revisão integrativa da literatura. Rev Eletron Estácio Saúde [Internet]. 2018 [cited 19 Dec 31];7(1). Available from: http://revistaadmmade.estacio.br/index.php/saudesantacatarina/article/ viewFile/3866/2034

19. Deméh W, Rosengren K. The visualisation of clinical leadership in the content of nursing education-a qualitative study of nursing students' experiences. Nurse Educ Today. 2015;35(7):888-93. https://doi.org/10.1016/j.nedt.2015.02.020

20. Rao BJ. Innovative teaching pedagogy in nursing education. Int J Nurs Educ Scholarsh. 2019;11(4):176-80. https://doi. org/10.5958/0974-9357.2019.00114.4

21. Rosenau PA, Lisella R, Clancy TL, Nowell L. Developing future nurse educators through peer mentoring. Nurs Res Rev. 2015;5:13-21. https:// doi.org/10.2147/NRR.S73432

22. Dyess SM, Sherman RO, Pratt BA, Chiang-Hanisko L. Growing nurse leaders: their perspectives on nursing leadership and today's practice environment. O J Issues Nurs. 2016;21(1):7. https://doi.org/10.3912/OJIN.Vol21No01PPT04

23. Ashworth L. Challenges and opportunities: the role of the district nurse in influencing practice education. Br J Community Nurs. 2020;25(8):402-6. https://doi.org/10.12968/bjcn.2020.25.8.402

24. Ginger T, Ritchie G. Supporting students undertaking the Specialist Practitioner Qualification in District Nursing. Br J Community Nurs. 2017;22(11):542-46. https://doi.org/10.12968/bjcn.2017.22.11.542 